\title{
Lexis
}

Journal in English Lexicology

Book reviews | 2008

\section{Alan CRUSE, A Glossary of Semantics and Pragmatics}

Edinburgh University Press, 2006, 198 pages

\section{Piotr Stalmaszczyk}

\section{Q OpenEdition}

\section{Journals}

\section{Electronic version}

URL: http://journals.openedition.org/lexis/1525

DOI: $10.4000 /$ lexis. 1525

ISSN: 1951-6215

\section{Publisher}

Université Jean Moulin - Lyon 3

\section{Electronic reference}

Piotr Stalmaszczyk, «Alan Cruse, A Glossary of Semantics and Pragmatics », Lexis [Online], Book reviews, Online since 22 March 2008, connection on 23 September 2020. URL : http://journals.openedition.org/ lexis/1525 ; DOl : https://doi.org/10.4000/lexis.1525

This text was automatically generated on 23 September 2020.

\section{(c) $($ ) $(9)$}

Lexis is licensed under a Creative Commons Attribution-NonCommercial-NoDerivatives 4.0 International License. 


\title{
Alan CRUSE, A Glossary of Semantics and Pragmatics
}

Edinburgh University Press, 2006, 198 pages

\author{
Piotr Stalmaszczyk
}

\section{REFERENCES}

\section{Alan Cruse}

A Glossary of Semantics and Pragmatics. Edinburgh University Press, 2006. ISBN :

978-0748621118, Prix : $12.38 €, 198$ pages

1 Alan Cruse's book is published as part of a series of thematic glossaries devoted to different fields of linguistics. Other titles published so far by Edinburgh University Press focus on morphology, phonology, English grammar, historical linguistics, cognitive linguistics, corpus linguistics, applied linguistics, language and mind. This volume is concerned with two disciplines: semantics and pragmatics.

2 The Glossary consists of four parts: a short introduction (pp. 1-5), the glossary (pp. 7-193), and two bibliographical sections (pp. 194-198). The introduction states that the Glossary is intended for "beginners as far as semantics and pragmatics are concerned" (p. 1). The introduction also explains which fields of language study are covered in the book, what their mutual relation is, and what their respective areas of research consist of. In this part, Cruse provides background information on the notions of semiotics, semantics and pragmatics (though without referring to the seminal work of Charles Morris). Interestingly, in the main body of the Glossary, pragmatics receives a separate entry (pp. 136-137), whereas semantics does not.

Cruse acknowledges that there are numerous different theoretical accounts of semantics and pragmatics, and he refers to his attempt to make the Glossary "as 'ecumenical' as possible, and to include all the main theoretical approaches" (p. 2). The introduction also explains the typographic conventions used throughout the Glossary and gives advice on using the book. 
The glossary proper includes around 500 entries, starting with "absolute adjectives" and ending with "zeugma". A considerable number of entries (almost 200!) consist solely of cross-references (there are 5 such examples on the very first page). Some are explained in only three or four lines (e.g. "antagonism", "punctual", "reading", "scripts"), whilst others receive more comprehensive treatment (e.g. "ambiguity", "conversational implicatures", "selectional restrictions"). Certain terms defined in the glossary are very general and have a wide scope ("cognitive linguistics", "semiotics"), others are rather basic, with their application not being limited to semantics/ pragmatics ("affix", "gender", "idiom", "word"), whereas still others are highly specialized and rare ("consequential scanning", "dot-objects", "exemplar theory", "protasis"). For obvious reasons several terms are connected with the neighbouring disciplines of logic (e.g. "material implication", "possible worlds semantics", "predicate calculus") and rhetoric (e.g. "irony", "simile").

It is not the aim of this short review to provide a list of terms which might have been included (always an easy task when discussing a thematic glossary, especially one dealing with such multidimensional disciplines). However, some cases of inconsistency should be mentioned. If there is an entry for "lexicology" (p. 96), one would also expect to find "lexicography" and "lexicon". Though there are entries for "meaningfulness" (p. 102) and "meaning postulates" (p. 103), there is no entry for "meaning", the key notion of semantics (it should be added however that there is also a separate entry for "dictionary meaning vs. encyclopaedic meaning"). There is an entry for "concepts, conceptual categories" (pp. 29-30) but not for "category" or "categorization".

6 The definitions are written in a clear style, often accompanied by appropriate examples and short dialogues. The language of explanations is lively, with occasional informal comments, as in the observation on the nature of conversational maxims: "think the Highway Code rather than table manners" (p. 101), or in the elucidation of the concept of possible worlds: "there is a possible world identical to our world except that I did not mis-type the currant sentence" (p. 134). Additionally, the entry for "lexical hierarchy" (pp. 94-95) employs diagrams to illustrate some aspects of the taxonomy.

7 The bibliographical section is organized into two parts: the bibliography proper which lists 14 works cited alphabetically by the author's name in the glossary (among them Austin, Chomsky, Grice, Langacker, Saussure, Wierzbicka and Wittgenstein), and a section on recommended readings further subdivided into more specific areas of research. It is very difficult to provide a comprehensive bibliography of two rapidly developing disciplines, especially in a book of limited size, but nevertheless some important additions might be suggested, namely Kempson's (1977) classic introduction to semantics, and other more formal overviews, such as de Swart (1998), Gazdar (1979), Heim and Kratzer (1998), Larson and Segal (1995), Kadmon (2001), and Portner (2005). Additionally, readers and collections of essential papers could have been included, e.g. Davis and Gillon, eds (2004), and Portner and Hall Partee, eds (2002). One more comment on the bibliography - there are errors in both the name and title of Katarzyna Jaszczolt's (2002) textbook.

8 There are few other misprints, probably the most confusing one in the entry for "propositional calculus" (p. 144), where the value for material implication with a false antecedent and false consequent should be 'true', not 'false' (as is clear from the discussion following the table). Also in the entry for "predicate calculus" (pp. 137-138), 
appropriate parentheses are missing from the examples illustrating the use of operators.

The above critical remarks notwithstanding, the overall evaluation of the book is definitely positive. Cruse's glossary provides necessary background information on the basic concepts used in (non-formal) semantics and pragmatics, it is easy to consult and should therefore prove useful for both beginners and researchers from outside both disciplines who need to check the basic (and also sometimes more advanced) terminology.

\section{BIBLIOGRAPHY}

DAVIS Steven and GILLON Brendan S. (eds.), Semantics. A Reader, Oxford, Oxford University Press, 2004.

DE SWART Henriëtte, Introduction to Natural Language Semantics, Stanford, CSLI Publications, 1998.

GAZDAR Gerald, Pragmatics: Implicature, Presupposition, and Logical Form, New York, Academic Press, 1979.

HEIM Irene and KRATZER Angelika, Semantics in Generative Grammar, 'Blackwell Textbooks in Linguistics', Oxford, Blackwell Publishing, 1998.

JASzCZOLT Katarzyna, Semantics and Pragmatics: Meaning in Language and Discourse, 'Longman Linguistics Library', London, Longman, 2002.

KADMON Nirit, Formal Pragmatics: Semantics, Pragmatics, Presupposition, and Focus, Oxford, Blackwell Publishers, 2001.

KEMPSON Ruth, Semantic Theory (Cambridge Textbooks in Linguistics), Cambridge, Cambridge University Press, 1977.

LARSON Richard and SEGAL Gabriel, Knowledge of Meaning. An Introduction to Semantic Theory, Cambridge, MA., MIT Press, 1995.

PORTNER Paul, What is Meaning? Fundamentals of Formal Semantics, 'Fundamentals of Linguistics', Oxford, Blackwell Publishing, 2005.

PORTNER Paul and hall PARTEE Barbara (ed.), Formal Semantics. The Essential Readings, Oxford, Backwell Publishing, 2002.

SZABó Zoltan Gendler (ed.), Semantics versus Pragmatics, Oxford, Clarendon Press, 2005.

\section{AUTHORS}

\section{PIOTR STALMASZCZYK}

Piotr Stalmaszczyk, Department of English and General Linguistics, University of Łódź, Poland 
Poland Piotr Stalmaszczyk is Professor of English and General Linguistics at the University of Łódź (Poland), head of the Department of English and General Linguistics, and Director of Institute of English Studies. His research interests are connected with the philosophy of language, linguistic methodology (especially generative grammar) and Celtic languages. 